\title{
ECONOMICS OF SWEET POTATO PRODUCTION IN BOKKOS LOCAL GOVERNMENT AREA OF PLATEAU STATE, NIGERIA
}

\author{
*Godfrey C. Onuwa ${ }^{1}$, Solomon T. Folorunsho ${ }^{2}$, Ganiyu Binuyo ${ }^{1}$, Mercy Emefiene $^{3}$ and \\ Onyekwere P. Ifenkwe ${ }^{4}$ \\ ${ }^{1}$ Department of Agricultural Extension and Management, Federal College of Forestry, Jos, \\ Plateau state, Nigeria. \\ ${ }^{2}$ Department of Agricultural Economics, University of Jos, Plateau state, Nigeria. \\ ${ }^{3}$ Department of Crop Production Technology, Federal College of Forestry, Jos, Plateau state, \\ Nigeria. \\ ${ }^{4}$ Department of Plant Science, University of Jos, Plateau state, Nigeria. \\ *Corresponding author: onuwag@gmail.com (08035606473)
}

\begin{abstract}
This study analyzed the economics of sweet potato production in Bokkos, Plateau State, Nigeria. Multi-stage sampling technique was adopted. Primary data collected was analyzed using descriptive statistics, gross margin and regression analysis. The results of the study revealed that the socioeconomic factors significantly affected sweet potato production. The estimated gross margin/ha was $\$ 154,150$. The estimated value of Sigma square $\left(\delta^{2}\right)$ was 0.699 , indicating that the model was well fitted for the data analysis. The coefficients of farm size (1.333), labour (0.439), fertilizer (0.452) and age (0.172) were positive and statistically significant at $p<0.05$ level; seed (0.362) was also positive and significant at $10 \%$ level; education (-0.639), household size (-0.472) and farm experience (-0.733) were negative but significant at $p<0.05$ level. Estimated mean technical efficiency index was 0.62, suggesting that farm yield can be increased by an index of 0.38, through improved management practices. The constraints identified significantly affected sweet potato production. Input subsidies, improved credit access, extension services, technology and market linkages are strongly recommended.
\end{abstract}

Keywords: Constraints, determinants of production, profitability, root crop, technical efficiency. 


\section{INTRODUCTION}

Sweet Potato (Ipomoea Batatas) is a root vegetable that produces tuberous roots (World atlas, 2019). It is a tropical root crop, with more than 133 million tons produced worldwide annually (Warammboi et al., 2011; Food and Agriculture Organization Statistics (FAOSTAT), 2007). Propagation is by adventitious roots, stem, or root cuttings (World atlas, 2019).China currently accounts for more than half of the total global sweet potato output at 70 million metric tons per annum, Nigeria ranks second among the world's largest producers of sweet potato with 3.4 million metric tons annually (World atlas, 2019), yet the average yield (4-10 tons/ha) are below the yield potential of about 25-30 tons/ha in China using similar labour intensive and technology (FAOSTAT, 2007). However, research works including those of Okonkwo and Okoli (2000) showed that while irrigated Irish potato production is an economically viable venture, it is more economically reasonable to cultivate (grow) sweet potato under rain fed condition in the study area: which implies that framers here monopolize the agro-ecological environment in growing this crop during the rainy season.Despite the importance of sweet potato, it is considered a minor crop in terms of production and consumption in Nigeria (Adewumi and Adebayo, 2008; Woolfe, 2002). The minimal utilization of sweet potato in Nigeria is obviously due to non-availability of adequate sweet potato- based recipes that satisfy the food habits of Nigerians (Adewumi and Adebayo, 2008; Warammboi et al., 2011). Of the estimated 200 million tons of all root and tubers produced in Nigeria annually, sweet potato contributes only 13\% (Horton, 2008; Ekwelle et al., 2001). Average yield under local conditions in the country is 4 tons per hectare. This is extremely low when compared to other countries such as China whereas much as 25 tons per hectare have been obtained through the use of modern production technologies and management systems (FAOSTAT, 2007). However, 10-15 tons per hectare is attainable by farmers in Nigeria using improved varieties (Okonkwo and Okoli, 2000). In Nigeria, the production, marketing and utilization of sweet potato have expanded to almost all the ecological zones within the past decade and 200,000 to 400,000 hectares of land are under sweet potato cultivation (Ekwelle et al., 2001; Adu-Kwarteng et al., 2002; FAOSTAT, 2007). The cultivation and utilization of sweet potato have not received appropriate attention of the Nigerian populace despite its nutritional constituents, ease of propagation, soil conservation attribute and industrial use (Woolfe, 2002). It was regarded as a crop with little economic importance. Its consumption was surrounded by the erroneous idea that it caused amoebic dysentery (Woolfe, 2002). Farmers paid no attention to improved management practices of sweet potato production. There's also a dearth of research on the improvement and husbandry of the crop. One serious problem facing Nigeria today is chronic and transitory food insecurity (World Bank, 2003). Sweet potato is highly regarded as a food security crop and it is the most productive crop among all the other staple crops and tolerates occasional dry spells and yields even on less fertile soil in contrast to other crops such as maize (Woolfe, 2002; Zuraida, 2003). World Bank (2003) opined that, despite the fact that Nigeria was found to be the second highest producer of sweet potato in the world, it was ranked $17^{\text {th }}$ in terms of output produced per land area, suggesting that sweet potato producers in Nigeria are quite inefficient in relation to farmers in other African countries. There is great need to improve the national production from 3 million to 10 million tons per annum (World Bank, 2003). This study seeks to provide information that would help the National Root Crop Research Institute (NRCRI) and other related research institutes and universities, to develop production technologies for sweet potato production and processing that would be relevant to the needs 
and problems of the farmers in the zone. It will also provide policy makers, development planners and workers with necessary data and insight for effective and sustainable policies and programmes that would facilitate adoption of sweet potato production and processing technologies. The study would, hopefully, add to the existing body of knowledge in rural sociology, extension and economics of root crop production. Therefore, the broad aim of this study was to analyze the economics of sweet potato production, while attempting to address the following research questions;

1. What are the socioeconomic characteristics of sweet potato farmers in the study area?

2. What is the cost and returns of sweet potato production?

3. What is the technical efficiency of sweet potato production?

4. What are the constraints of sweet potato production?

\section{METHODOLOGY}

Study Area: This study was carried out in Bokkos Local Government Area (LGA) of Plateau State, Nigeria. It has a total area of $1682 \mathrm{~km}^{2}$ and located between latitude $9^{0} 15^{\prime} \mathrm{N}$ and $8^{0} 53 \mathrm{E}$, with a total projected population of 392,026 in 2016 (FAOSTAT, 2007). The Local Government is made up of 8 districts which include; Mushere, Daffo, Richa, Sha, Manguna, Toff, Kamoi and Bokkos. The LGA is located at the central region of Plateau State and it is surrounded by rocks and scattered vegetation. Its Annual rainfall averages from $600 \mathrm{~mm}-$ $1000 \mathrm{~mm}$, with average temperatures of about $24^{\circ} \mathrm{C}-29^{0} \mathrm{C}$ annually (FAOSTAT, 2007). The major crops cultivated in the study area are Irish potato, sweet potato, cocoyam, maize and red beans.

Sampling Technique: Multi-stage sampling technique was used in selecting the respondents for the study. The first stage involved the Purposive selection of Bokkos LGA due to the prevalence of sweet potato production in the study area. The second stage involved the random sampling of three (3) districts out of eight (8) in the study area due to the prevalence of sweet potato farmers in the selected districts (Daffo, Sha and Bokkos districts). The third stage involved the collection of a list of sweet potato farmers from the extension agent at the Local Government secretariat. The last stage involved random selection of respondents from the list using constant sampling proportion of $20 \%$ of the sample frame. Consequently, a total of 92 respondents were selected as shown in Table 1, however only 90 questionnaires were retrieved for the purpose of this study.

Method of Data Collection: Data for this study was collected from primary source. Primary data was collected through the use of well-structured questionnaires in line with the specific objectives of the study.

Method of Data Analysis: The analytical tools used were; descriptive statistics (such as percentages, frequency distribution, mean) to analyze objectives i and iv, Gross margin analysis to analyze objective iiand stochastic frontier production model was used to analyze objective iii.

Gross Margin Analysis: It is a very essential planning tool in situation where fixed capital is a negligible portion of the farming enterprise as is a case in subsistence agriculture (Olukosi and Ogungbile, 1989). The gross margin analysis is expressed as; 
$\mathrm{GM}=\mathrm{GFI}-\mathrm{TVC}$

Where;

$\mathrm{GM}=$ Gross Margin $(\AA / H a) ; \mathrm{GFI}=$ Gross Farm Income $(\AA / \mathrm{Ha})$; and TVC $=$ Total Variable Cost ( $(\mathrm{H} / \mathrm{Ha})$

Stochastic Frontier Regression Analysis: The stochastic frontier production function model was employed to analyze objective (iii). The stochastic production function with a multiplicative disturbance term is of the form:

$\mathrm{Y}=\mathrm{f}(\mathrm{X} \beta)+\mathrm{e}_{\mathrm{i}}$

Where $\mathrm{Y}$ is the farm output in $\mathrm{kg}, \mathrm{X}$ is a vector of input quantities; $\beta$ is a vector of parameters and $\mathrm{e}$ is a stochastic disturbance term consisting of two independent elements $\mathrm{U}$ and $\mathrm{V}$, given by:

$\mathrm{e}_{\mathrm{i}}=\mathrm{v}-\mathrm{u}$

The empirical model stochastic frontier production function used in this study is specified in a double log form of Cobb- Douglas production function as follows:

In $Y i=\beta_{0}+\beta_{1} \operatorname{In} X_{1}+\beta_{2} \operatorname{In} X_{2}+\beta_{3} \operatorname{In} X_{3}+\beta_{4} \operatorname{In} X_{4}+\beta_{5} \operatorname{In} X_{5}+V i-U_{i}$

Where;

In = natural logarithm to base $\mathrm{e}$,

$\mathrm{Yi}=$ output of sweet potato $(\mathrm{kg} / \mathrm{ha})$

$V_{i}=$ assumed independently distribute random error or random stocks which are outside the farmer's control

$\mathrm{U}_{\mathrm{i}}=$ technical inefficiency effects which captures deviation from the frontier.

$\beta_{0}=$ intercept

$\beta_{1}-\beta_{5}=$ Unknown parameters which are to be determined.

$\mathrm{X}_{1}=$ farm size (ha)

$\mathrm{X}_{2},=$ quantity of seed used $(\mathrm{kg} / \mathrm{ha})$

$\mathrm{X}_{3}$, = labour (man-days)

$\mathrm{X}_{4}$, = quantity of fertilizer used $(\mathrm{kg} / \mathrm{ha})$

$\mathrm{X}_{5},=$ agrochemical (litres/ha)

Technical Inefficiency: The average level of technical inefficiency measured by mode of truncated normal distribution has been assumed to be a function of socioeconomic factors. 
Thus, technical inefficiency can be regarded as a function of socioeconomic characteristics and internal transaction costs. It is assumed that these inefficiency effects are independently distributed and $U_{i j}$ arises by truncation (at zero) of the normal distribution with mean $U_{i j}$ and variance $\alpha_{\mathrm{u}}$, where $\mathrm{U}_{\mathrm{ij}}$ is the technical inefficiency and its determinants in crop production specified as;

$\mathrm{U}_{\mathrm{i}}=\alpha_{0}+\alpha_{1} \mathrm{Z}_{1}+\alpha_{2} \mathrm{Z}_{2}+\alpha_{3} \mathrm{Z}_{3}+\alpha_{4} \mathrm{Z}_{4}+\alpha_{5} \mathrm{Z}_{5}+\mathrm{W}_{\mathrm{it}}$

Where:

$\mathrm{U}_{\mathrm{i}}=$ the technical inefficiency of the ith farmer

$\alpha_{0}=$ intercept

$\alpha_{1}-\alpha_{5}=$ Unknown parameters which are to be determined.

$\mathrm{z}_{1}=$ Age (years)

$\mathrm{z}_{2}=$ Gender $(1=$ male $0=$ female $)$

$\mathrm{Z}_{3}=$ Education level (years)

$\mathrm{Z}_{4}=$ Household size (number)

$\mathrm{Z}_{5}=$ Farming experience (years)

$\mathrm{W}_{\mathrm{it}}=$ is the random variable which is defined by the truncation of the normal distribution with zero mean and variance.

\section{RESULTS AND DISCUSSION}

\section{Socioeconomic Characteristics of the Respondents}

Table 1: Summary Statistics of Respondents' Socioeconomic Characteristics

\begin{tabular}{lccl}
\hline Variable & Mean & Frequency & Percentage (\%) \\
\hline Age (years) & 44 & & \\
Gender (Female) & & 57 & 63.3 \\
Marital status (married) & & 83 & 92.2 \\
Household size & 7 & & \\
Educational level(years) & 11 & & \\
Experience(years) & 18 & & \\
Farm size (ha) & 1 & & \\
Seed (g) & 800 & & \\
Labour (man-days) & 64 & & \\
Fertilizer (kg) & 250 & & \\
Agrochemical (litres) & 10 & & \\
\hline
\end{tabular}

Source: Field survey 2017

Table 1 revealed that the mean age of the respondents was 44years, implying that Majority of the respondents were in their economic and productive ages, this result implies a great 
prospective for sustainable production in the study area. The analysis of gender of respondents shows that production in the study area was dominated by women (63.3\%).Gender is an essential socio economic factor that can affect agricultural production in Nigeria. The results also showed that majority (92.2\%) of the respondents were married, implying that households in the study area will have more access and supply of farm labour. The respondents have a mean household size of 7 members per household. The larger the size of the household the more labour force is available for farm activities. This implies that household in the study area had adequate labour supply to embark on expansionary farming activities which will result in an increasing productivity rate and reduce labour cost. The mean years spent in school was 11 years. This implies that majority of the respondents were literates and had basic education backgrounds, which enhances their productive capacities. Research has shown that access to education enables households in rural areas to adopt new agricultural methods, cope with risk, respond to market signals and improve agricultural productivity. The respondents have a mean farming experience of 27 years. The result opined that respondents will have adequate experience necessary for increased production. This shows that the managerial ability of farmers can be inferred to be reasonably good. The more experienced a farmer is the more efficient his decision making processes and more he will be willing to take risks associated with adoption of innovation to increase his production. Farming experience is the act of gaining knowledge through constant practicing of skill, which brings about specialization. Experience enhances more efficient use of scarce resources by arable crop farmers, the mean farm size was 1 ha, implying that most of the farmers in the study area were producing at subsistent level. Findings also revealed that the average quantity of sweet potato seed (vines/stems) used by the respondents was 800 grams, 64 man-days of labour was employed by the respondents on their farms, while an average of $250 \mathrm{~kg}$ of fertilizer and 10litres of agrochemical (herbicides) was applied by the respondents on their sweet potato farms. This result corroborates with the findings of Ajetomba (2005) and Olarinde et al. (2005) who also reported similar results.

Gross Margin Analysis of Sweet Potato Production

Table 2: The Gross Margin Analysis of Sweet Potato Farmers

\begin{tabular}{lll}
\hline Input & $\$ /$ Hectare & $(\%)$ \\
\hline Returns: & & \\
Mean output/ha =3,000kg & & \\
Unit price/50kg bag = $\begin{array}{l}\text { T3,500 } \\
\text { Total Revenue (TR) }\end{array}$ & 210,000 & \\
Variable cost (VC): & & \\
Labour & 15,000 & 26.85 \\
Seed & 7,000 & 12.53 \\
Fertilizer & 18,500 & 33.12 \\
Herbicide & 2,500 & 4.48 \\
Empty bag(s) & 4,500 & 8.07 \\
Farm implements & 3,850 & 6.89 \\
Tax/levy & 500 & 0.9 \\
Transportation/Storage cost & 4,000 & 7.16 \\
Total Variable Cost(TVC) & 55,850 & \\
Gross margin (TR - TVC) & 154,150 & \\
\hline Source: Fin
\end{tabular}

Source: Field survey 2017 
Table 2 revealed the result of the Gross margin analysis. It revealed that the total variable cost (TVC) of producing sweet potato in the study area was 55,850/ha while the total revenue was $\$ 210,000 /$ ha. Fertilizer $(33.12 \%$ ) constituted the highest cost with $\$ 18,500 /$ ha, followed by labour cost $(26.85 \%)$ with $\$ 15,000 /$ ha. The result also revealed that the production of sweet potato in the study area is profitable with a gross margin of 154,150/ha. This result corroborates with the findings of Olarinde et al. (2005) who reported similar result on the profitability of arable crop production.

\section{Regression Analysis of Sweet Potato Production}

Table 3: $\quad$ Stochastic Frontier Analysis of Sweet Potato Production

\begin{tabular}{lllll}
\hline Variable & Parameter & Coefficient & Standard error & T-ratio \\
\hline
\end{tabular}

Efficiency model:

$\begin{array}{llllr}\text { Constant } & \beta_{0} & 2.721^{* *} & 0.983 & 2.768 \\ \text { Farm size }\left(\mathrm{x}_{1}\right) & \beta_{1} & 1.333^{* *} & 0.472 & 2.824 \\ \text { Seed }\left(\mathrm{x}_{2}\right) & \beta_{2} & 0.362^{*} & 0.202 & 1.792 \\ \text { Labour }\left(\mathrm{x}_{3}\right) & \beta_{3} & 0.439^{* *} & 0.164 & 2.676 \\ \left.\text { Fertilizer( } \mathrm{x}_{4}\right) & \beta_{4} & 0.452^{* *} & 0.139 & 3.251 \\ \text { Herbicides }\left(\mathrm{x}_{5}\right) & \beta_{5} & 0.766^{\mathrm{n} . \mathrm{s}} & 0.681 & 1.124 \\ \text { Inefficiency model: } & & & & \\ \text { Constant } & \alpha_{0} & 2.273^{* *} & 0.891 & 2.551 \\ \text { Age }\left(\mathrm{z}_{1}\right) & \alpha_{1} & -0.172^{* *} & 0.055 & -3.127 \\ \text { Gender }\left(\mathrm{z}_{2}\right) & \alpha_{2} & 1.281^{\mathrm{n} . \mathrm{s}} & 0.923 & 1.387 \\ \text { Education }\left(\mathrm{z}_{3}\right) & \alpha_{3} & -0.639^{* *} & 0.218 & -2.931 \\ \text { Household size }\left(\mathrm{z}_{4}\right) & \alpha_{4} & -0.472^{* *} & 0.139 & -3.395 \\ \text { Experience }\left(\mathrm{z}_{5}\right) & \alpha_{5} & -0.733^{* *} & 0.229 & -3.201\end{array}$

Variance parameter:

\begin{tabular}{lllll} 
Sigma-square & $\left(\sigma^{2}\right)$ & $0.699 * *$ & 0.251 & 2.784 \\
\hline
\end{tabular}

Source: field survey $2017 ; * *=5 \%(\mathrm{p}<0.05),{ }^{*}=10 \%(\mathrm{p}<0.1)$

The estimates of the parameters of the stochastic frontier model are presented in Table 3 . The estimated value of Sigma square $\left(\delta^{2}\right)$ was 0.699 . The value was significantly different from zero at $5 \%(\mathrm{p}<0.05)$ level. This indicates a goodness of fit of the model for the analysis. The 
result revealed that coefficients of farm size (1.333), labour $(0.439)$ and fertilizer $(0.452)$ were positive and statistically significant at $5 \%(\mathrm{p}<0.05)$ level, also the coefficient of seed $(0.362)$ was positive and statistically significant at $10 \%(\mathrm{p}<0.1)$ level, implying that an increase in these variables will increase the level of output. This is in line with the findings of Okonkwo and Okoli (2000) and Tewe et al. (2003), who reported positive relationships between inputs and output in crop production. The inefficiency model revealed that the coefficient of age $(0.172)$ was positive and statistically significant at $5 \%(\mathrm{p}<0.05)$ level. This implies that increase in age will reduce the technical efficiency of the farmer, while the coefficients of education (-0.639), household size (-0.472) and farming experience $(-0.733)$ were negative, but statistically significant at $5 \%(\mathrm{p}<0.05)$ level, implying that an increase in these variables will significantly reduce the inefficiency in sweet potato production, thereby, increasing technical efficiency.

\section{Technical Efficiency Index}

Table 4: Distribution of respondents based on their technical efficiency index

Efficiency index $\quad$ Frequency Percentage (\%)

\begin{tabular}{lll}
\hline $0.31-0.40$ & 10 & 11.1 \\
$0.41-0.50$ & 41 & 45.6 \\
$0.51-0.60$ & 15 & 16.7 \\
$0.61-0.70$ & 12 & 13.3 \\
$0.71-0.80$ & 7 & 7.8 \\
$0.81-0.90$ & 3 & 3.3 \\
$0.91-1.00$ & 2 & 2.2 \\
Total & 90 & 100 \\
Minimum 0.33 & & \\
Maximum 0.91 & & \\
Mean 0.62 & & \\
\hline
\end{tabular}

Source: Computed from MLE results 2017

The technical efficiency of sampled farmers was less than one $(<100 \%)$ implying that all the farmers in the study area are producing below maximum efficiency frontier. From the observed range of technical efficiency across the sampled farmers, the best farmer had a technical efficiency index of $0.91(91 \%)$, while the least farmer had a technical efficiency of 
$0.33(33 \%)$. The mean technical efficiency was $0.62(62 \%)$ implying that on the average, farmers in the study area were able to obtain average of $62 \%$ optimal output from a given mix of production inputs. The mean technical efficiency estimated indicates that the realized output could be increased by about $38 \%$ by adopting the best practices. The magnitude of the mean technical efficiency of the farmers is a reflection of the fact that most of the sampled farmers carry out sweet potato production under inadequate technical conditions. From this estimation, maximum technical efficiency is not yet achieved suggesting a need for more effort at improving efficiency of sweet potato farmers in the study area. The distribution of technical efficiency index of the farmers shows that, most $(45.6 \%)$ of the sweet potato farmers had technical efficiency index ranging between $0.41-0.50$, while the least $(2.2 \%)$ technical efficiency index of the sweet potato farmers were between 0.91-100.

\section{Constraints of Sweet Potato Production}

Table 5: Constraints of sweet potato production

\begin{tabular}{lll}
\hline Constraints & Frequency & Percentage $(\%)^{*}$ \\
\hline High cost of labour & 65 & 72.2 \\
Financial constraints & 82 & 91.1 \\
Poor storage facility & 71 & 78.9 \\
Pest and diseases & 46 & 51.1 \\
Poor access to improved technology & 53 & 58.9 \\
Lack of extension contacts & 34 & 37.8 \\
Low patronage due to predominance of similar crop(s) & 37 & 41.1 \\
High cost of improved technology/inputs & 89 & 98.9 \\
\hline
\end{tabular}

Source: field survey $2017 ; *$ Multiple responses allowed

The result of Table 5 revealed that the constraints of sweet potato production in the study area include; high cost of improved technology/inputs (98.9\%), financial constraints (91.1\%), poor storage facilities $(78.9 \%)$, high cost of labour $(72.2 \%)$, poor access to improved technology $(58.9 \%)$, pest and diseases $(51.1 \%)$, low patronage due to predominance of similar crop(s) (41.1\%) and lack of extension contact (37.8\%). All the constraints identified by the farmers significantly affected sweet potato production in the study area. This result is in line with the findings of Benjamin et al. (2014); Nwankwo (2008); National Root Crop Research Institute (NRCRI) (2000), who also reported similar constraints in arable crop production.

\section{CONCLUSION AND RECOMMENDATIONS}

This study analyzed the economics of sweet potato production in Bokkos LGA of Plateau State, Nigeria. The results revealed that the socioeconomic characteristics of the respondents significantly affected sweet potato production in the study area. The gross margin analysis revealed that sweet potato production is a relatively profitable enterprise under poor soil conditions. The stochastic production analysis indicated that the coefficients of the variables in the efficiency and inefficiency models were statistically significant. This implies that efficient resource utilization in sweet potato production can increase farm output resulting in increased farm household incomes and food security status. The mean technical efficiency index indicated an average of $62 \%$ optimal outputs 
from a given mix of production inputs by farmers in the study area. The constraints identified also significantly affected sweet potato production in the study area. Based on the findings of this study, the following recommendations are made to improve the output of sweet potato production in the zone;

i. Formulation of policies to subsidize cost of improved production technology and inputs.

ii. Cooperative formation to improve farmers' access to agricultural credit.

iii. Formulation of policies to increase farmer-extension contacts.

iv. Formulation of policies to encourage the development of indigenous production, storage and processing technologies.

v. Formulation of policies to encourage efficient adoption of improved management practices, pest and disease control measures.

vi. Formulation of policies to improve market linkages for harvested produce. 


\section{REFERENCES}

Adewumi, M.O. \& Adebayo, F.A. (2008), Profitability and technical efficiency of sweet potato production in Nigeria. Journal of Rural Development 31(5): 105-120.

Adu-Kwarteng, E., Otoo, J. A., Osei, C. K., \& Baning, I. S. (2002), Sweet potato: The Crop of the Future. Fact sheet Published by the Communications and Extension Division of Crops Research Institute - Council for Scientific and Industrial Research, Ghana.

Ajetomba, J.O. (2005), Socio-economic characteristics and profitability of contact farmers in Oyo agricultural Zone in a deregulated economy. Journal of Social service. 11(3).17718117.

Benjamin, M. K., Francis J. M., Stephen M. G., Craig G. Y., \& Julia, S. (2014), “Assessment of production constraints and farmers' preferences for sweet potato genotypes". J. plant breeds genetics. 02 (01) 2014. 15-29.

Ekwelle, M. C., Ezulike, T. O. \& Eke-Okoro, O.N. (2001), Contributions of root and tuber crop to the Nigerian economy. In; M. O. Akoroda (ed) Root crops: The small processor and development of local food industry for market economy. Proceedings of the $8^{\text {th }}$ triennial symposium of the International Society for Tropical Root Crops Africa Branch.

Food and Agriculture Organization Statistics (FAOSTAT, 2007), Food and agriculture commodities production: Countries by commodity. Top production of sweet potato2007. http://faostat.foa.org/site/339/default.aspx.

Horton, D. (2008): “Underground Crops. Long Term Trends in Production of Roots and Tubers", Winrock International Institute for Agricultural Development, Arhington, USA. $\quad$ https://worldatlas.com/articles/top-sweet-potato-growing-countries.html; retrieved 9/27/2019.

Nigerian Root Crop Research Institute (NRCRI 2000), Sweet Potato Varieties, Nigerian Root Crop Research Institute newsletter.

Nwankwo, S. (2008), Access to formal credit by farmers for agricultural enterprise development. A survey report.

Olarinde, L.O., Ajao A. O. \&Ajetomba, J.O. (2005), Socioeconomic characteristics and profitability of contact farmers in Oyo agricultural Zone in a deregulated economy. Journal of Social service 11(3).177-18117.

Okonkwo, J.C. \&Okoli L.S.O (2000). Potato production in Jos plateau; Report of survey of Potato production in four (4) Local Government Areas of Plateau state of Nigeria, NCRI, Vom, Nigeria.

Olukosi J.O and Ogungbile A. O (1989): "Introduction to Agricultural Production Economics, Principles and Applications", Zaria, Nigeria. 
Tewe, O.O., Ojeniyi, F.E., \& Abu, O.A. (2003), Sweet potato production, utilization and marketing in Nigeria, Social Sciences Department International Potato Centre, Lima, Peru. Accessed October 2010. Available at http://www.eseap.cipotatoorg/MFESEAP/F/-Library/spinNigeria.pdf.

Warammboi, J. G., Dennien, S., Gidley, M. J., \&Sopade, P. (2011), Characterization of Sweet potato from Papua New Guinea and Australia: Physicochemical, Pasting and Gelatinization Properties. Food Chemistry, 126, 1759-1770. http://dx.doi.org/10.1016 jj.foodchem.2010.12.077.

Woolfe J. A. (2002), Sweet Potato: An Untapped Resource”. Press Syndicate of Cambridge, UK.

World Bank (2003), Delivering the Food to Africa, World Food Programme, Journal of World Bank Agricultural Economics.

Zuraida, N. (2003), Sweet potato as an alternative Food Supplement during Rice Shortage. Jurnal Litbang Pertanian, 22(4). 